\title{
Alkaloids from a deep ocean sediment-derived fungus Penicillium sp. and their antitumor activities
}

\author{
Lin $\mathrm{Du}^{1}$, Teng Feng ${ }^{1}$, Boyu Zhao ${ }^{1}$, Dehai $\mathrm{Li}^{1}$, Shengxin Cai ${ }^{1}$, Tianjiao $\mathrm{Zhu}^{1}$, Fengping Wang ${ }^{2}$, Xiang Xiao ${ }^{2}$ \\ and Qianqun $\mathrm{Gu}^{1}$
}

Four new alkaloids, including two new meleagrin analogs, meleagrin $D(1)$ and $E(2)$, and two new diketopiperazines, roquefortine $\mathrm{H}$ (3) and I (4), were isolated from a deep ocean sediment-derived fungus Penicillium sp. Meleagrin D (1) and $E$ (2) possess unprecedented acetate-mevalonate-derived side chains on the imidazole moiety. These new meleagrins showed weak cytotoxicity against the A-549 cell line, whereas meleagrin B (5) and meleagrin (6), which were isolated previously from the same strain, induced HL-60 cell apoptosis or arrested the cell cycle through $G_{2} / M$ phase, respectively. The results indicate that the distinct substitutions on the imidazole ring significantly influence the cytotoxicity of the meleagrin alkaloids. The Journal of Antibiotics (2010) 63, 165-170; doi:10.1038/ja.2010.11; published online 26 February 2010

Keywords: alkaloid; deep ocean; fungus; Penicillium sp.

\section{INTRODUCTION}

The meleagrin and roquefortine groups, mainly isolated from Penicillium species, are biogenetically interrelated alkaloids ${ }^{1-7}$ with promising biological properties, such as neurotoxic, ${ }^{1}$ antibacterial, ${ }^{8}$ cytochrome P450 inhibitory ${ }^{9}$ and tubulin polymerization inhibitory activity. ${ }^{10}$ We have previously reported on meleagrin B (5), a novel complex compound composed of a meleagrin alkaloid moiety and a rare diterpene moiety, from a deep ocean sediment-derived fungus Penicillium sp. F23-2. ${ }^{11}$ Meleagrin B (5) showed potent cytotoxicity against four tumor cell lines, with $\mathrm{IC}_{50}$ values ranging from 1.8 to $6.7 \mu \mathrm{M}$. In an effort to obtain more insight into the biosynthetic mechanisms and structure-activity relationships in this family of metabolites, we investigated the active constituents of this fungus, which led to the isolation of four new alkaloids, meleagrin $\mathrm{D}(\mathbf{1})$, meleagrin E (2), roquefortine $\mathrm{H}(3)$ and roquefortine I (4). Compounds 1 and 2 possess unprecedented side chains, which originated from six acetates via the acetate-mevalonate pathway, on the imidazole moiety. They showed weak cytotoxicity against the A-549 cell line, while the alkaloid nucleus, meleagrin (6), exhibited moderate cytotoxicity against the A-549 and HL-60 cell lines, with the $\mathrm{IC}_{50}$ values being 19.9 and $7.4 \mu \mathrm{M}$, respectively. Comparison with the previous antitumor evaluation of meleagrin $\mathrm{B}(5)$ and $\mathrm{C}^{11}$ suggests that addition of the acetate-mevalonate-derived $\mathrm{C} 5$ or $\mathrm{C} 9$ side chains on $\mathrm{N}-17$ negatively affects the activities of meleagrin alkaloids, while the diterpene substitution on the imidazole ring enhances the cytotoxic activities. On further exploring the cytotoxic mechanisms of meleagrin B (5) and meleagrin (6) by flow cytometric analysis, meleagrin B (5) induced the HL-60 cell apoptosis at 5 and $10 \mu \mathrm{M}$, while meleagrin (6) arrested the cell cycle through $\mathrm{G}_{2} / \mathrm{M}$ phase at the same concentrations. This analysis indicates that addition of the diterpene moiety on the imidazole ring endows the molecules with distinct cytotoxic mechanisms. In this paper, we describe the isolation, structure elucidation and analysis of the cytotoxicity against A-549 and HL-60 cell lines of the new compounds, and the flow cytometric analysis of meleagrin B (5) and meleagrin (6) on the HL-60 cell line.

\section{RESULTS AND DISCUSSION}

Structure determination

Compound 1 was obtained as a yellow solid. Its molecular formula $\left(\mathrm{C}_{32} \mathrm{H}_{38} \mathrm{~N}_{5} \mathrm{O}_{5}\right)$ was determined by HR-ESI-MS ( $\mathrm{m} / \mathrm{z} 572.2852$ $[\mathrm{M}+\mathrm{H}]^{+}$, calcd for 572.2873), indicating 15 degrees of unsaturation. The ${ }^{1} \mathrm{H}$ NMR spectrum showed a characteristic $\mathrm{ABCD}$ system due to the aromatic resonances $(\delta 7.52(1 \mathrm{H}, \mathrm{d}, J=7.8 \mathrm{~Hz}, \mathrm{H}-4), 7.03(1 \mathrm{H}, \mathrm{t}$, $J=7.8 \mathrm{~Hz}, \mathrm{H}-5), 7.25(1 \mathrm{H}, \mathrm{t}, J=7.8 \mathrm{~Hz}, \mathrm{H}-6), 6.95(1 \mathrm{H}, \mathrm{d}, J=7.8 \mathrm{~Hz}$, H-7)) with the typical multiplets due to ortho- and meta-couplings. Analysis of the ${ }^{13} \mathrm{C}$ NMR and DEPT spectra revealed 13 quaternary carbons, 10 methines, 2 methylenes and 7 methyls. Comparison of the ${ }^{1} \mathrm{H}$ and ${ }^{13} \mathrm{C}$ NMR data (Table 1) with those of the known compounds, meleagrin B (5), ${ }^{11}$ meleagrin $(6)^{12}$ and meleagrin $C,{ }^{11}$ indicated that the structure of 1 included a $N$-methoxyindoline moiety $\left(\delta_{\mathrm{C}} 65.3\right.$ $\left(\mathrm{OCH}_{3}-1\right), 100.8(\mathrm{C}-2), 52.1(\mathrm{C}-3), 125.6(\mathrm{C}-3 \mathrm{a}), 124.9(\mathrm{C}-4), 123.6$ (C-5), 128.5 (C-6), 112.1 (C-7), 146.3 (C-7a)), a 1,1-dimethyl-2propenyl group $\left(\delta_{\mathrm{H}}\right.$ : geminal methyl, $1.23\left(3 \mathrm{H}, \mathrm{s}, \mathrm{CH}_{3}-24\right)$ and 1.35 $\left(3 \mathrm{H}, \mathrm{s}, \mathrm{CH}_{3}-25\right)$; terminal olefin, $6.08(1 \mathrm{H}$, brs, $\mathrm{H}-22), 5.14(1 \mathrm{H}, \mathrm{brd}$,

\footnotetext{
${ }^{1}$ Key Laboratory of Marine Drugs, Chinese Ministry of Education School of Medicine and Pharmacy, Institute of Marine Drugs and Food, Ocean University of China, Qingdao, PR China and ${ }^{2}$ School of Life Science \& Biotechnology, Shanghai Jiao Tong University, Shanghai, PR China

Correspondence: Dr Q Gu, Key Laboratory of Marine Drugs, Chinese Ministry of Education School of Medicine and Pharmacy, Institute of Marine Drugs and Food, Ocean University of China, 5 Yushan Road, Qingdao 266003, PR China.

E-mail: guqianq@ouc.edu.cn

Received 20 October 2009; revised 15 January 2010; accepted 20 January 2010; published online 26 February 2010
} 
Table $1{ }^{1} \mathrm{H}(600 \mathrm{MHz})$ and ${ }^{13} \mathrm{C}(150 \mathrm{MHz})$ NMR data for compounds 1 and 2 in $\mathrm{CDCl}_{3}$

\begin{tabular}{|c|c|c|c|c|}
\hline \multirow[b]{2}{*}{ NO } & \multicolumn{2}{|l|}{1} & \multicolumn{2}{|l|}{2} \\
\hline & $\delta_{H}(\mathrm{~J}$ in $\mathrm{Hz})$ & $\delta_{C}$ & $\delta_{H}(\mathrm{~J}$ in $H z)$ & $\delta_{C}$ \\
\hline $1-\mathrm{OCH}_{3}$ & $3.72(3 \mathrm{H}, \mathrm{s})$ & 65.3 & $3.64(3 \mathrm{H}, \mathrm{s})$ & 65.3 \\
\hline 2 & & 100.8 & & 100.8 \\
\hline 3 & & 52.1 & & 52.1 \\
\hline $3 a$ & & 125.6 & & 125.6 \\
\hline 4 & $7.55(1 \mathrm{H}, \mathrm{d}, 7.7)$ & 124.9 & $7.52(1 \mathrm{H}, \mathrm{d}, 7.8)$ & 124.8 \\
\hline 5 & $7.05(1 \mathrm{H}, \mathrm{t}, 7.7)$ & 123.6 & $7.03(1 \mathrm{H}, \mathrm{t}, 7.8)$ & 123.5 \\
\hline 6 & $7.25(1 \mathrm{H}, \mathrm{t}, 7.7)$ & 128.5 & $7.25(1 \mathrm{H}, \mathrm{t}, 7.8)$ & 128.4 \\
\hline 7 & $6.95(1 \mathrm{H}, \mathrm{d}, 7.7)$ & 112.1 & $6.95(1 \mathrm{H}, \mathrm{d}, 7.8)$ & 112.1 \\
\hline $7 a$ & & 146.3 & & 146.3 \\
\hline 8 & $5.45(1 \mathrm{H}, \mathrm{s})$ & 107.1 & $5.20(1 \mathrm{H}, \mathrm{s})$ & 107.1 \\
\hline 9 & & 141.9 & & 142.3 \\
\hline 10 & & 158.8 & & 158.8 \\
\hline 12 & & 123.6 & & 123.5 \\
\hline 13 & & 163.7 & & 163.7 \\
\hline 15 & $8.45(1 \mathrm{H}, \mathrm{s})$ & 117.7 & $8.17(1 \mathrm{H}, \mathrm{s})$ & 117.1 \\
\hline 16 & & 135.3 & & 135.4 \\
\hline 18 & $7.62(1 \mathrm{H}, \mathrm{s})$ & 134.4 & $7.84(1 \mathrm{H}, \mathrm{s})$ & 134.4 \\
\hline 20 & $8.59(1 \mathrm{H}, \mathrm{s})$ & 122.2 & $8.35(1 \mathrm{H}, \mathrm{s})$ & 121.9 \\
\hline 21 & & 42.8 & & 42.7 \\
\hline 22 & $6.08(1 \mathrm{H}, \mathrm{brs})$ & 143.3 & $6.07(1 \mathrm{H}, \mathrm{brs})$ & 143.3 \\
\hline $23 a$ & $5.14(1 \mathrm{H}$, brd, 17.6$)$ & 114.1 & $5.03(1 \mathrm{H}$, brd, 16.5$)$ & 114.1 \\
\hline $23 b$ & $5.08(1 \mathrm{H}, \mathrm{brs})$ & & $4.98(1 \mathrm{H}, \mathrm{brs})$ & \\
\hline 24 & $1.23(3 \mathrm{H}, \mathrm{brs})$ & 23.0 & $1.18(3 \mathrm{H}, \mathrm{s})$ & 23.0 \\
\hline 25 & 1.35 (3H, brs) & 21.7 & $1.18(3 \mathrm{H}, \mathrm{s})$ & 21.7 \\
\hline $1^{\prime}$ & & 157.1 & & 69.7 \\
\hline $2^{\prime} \mathrm{a}$ & $5.78,(1 \mathrm{H}, \mathrm{s})$ & 124.1 & $2.40(1 \mathrm{H}, \mathrm{d}, 16.1)$ & 54.9 \\
\hline $2^{\prime} b$ & & & $2.35(1 \mathrm{H}, \mathrm{d}, 16.1)$ & \\
\hline $3^{\prime}$ & & 196.8 & & 208.7 \\
\hline $4^{\prime} a$ & $2.86(1 \mathrm{H}, \mathrm{s})$ & 55.9 & $3.02(1 \mathrm{H}, \mathrm{d}, 16.5)$ & 55.3 \\
\hline $4^{\prime} \mathrm{b}$ & $2.86(1 \mathrm{H}, \mathrm{s})$ & & $2.95(1 \mathrm{H}, \mathrm{d}, 16.5)$ & \\
\hline $5^{\prime}$ & & 57.0 & & 56.4 \\
\hline $6^{\prime}$ & $2.08(3 \mathrm{H}, \mathrm{s})$ & 20.8 & $1.14(3 \mathrm{H}, \mathrm{s})$ & 29.4 \\
\hline $7^{\prime}$ & $1.79(3 \mathrm{H}, \mathrm{s})$ & 27.7 & $1.14(3 \mathrm{H}, \mathrm{s})$ & 29.4 \\
\hline $8^{\prime}$ & $1.71(3 \mathrm{H}, \mathrm{s})$ & 28.1 & $1.72(3 \mathrm{H}, \mathrm{s})$ & 28.3 \\
\hline $9^{\prime}$ & $1.71(3 \mathrm{H}, \mathrm{s})$ & 28.1 & $1.71(3 \mathrm{H}, \mathrm{s})$ & 28.2 \\
\hline
\end{tabular}
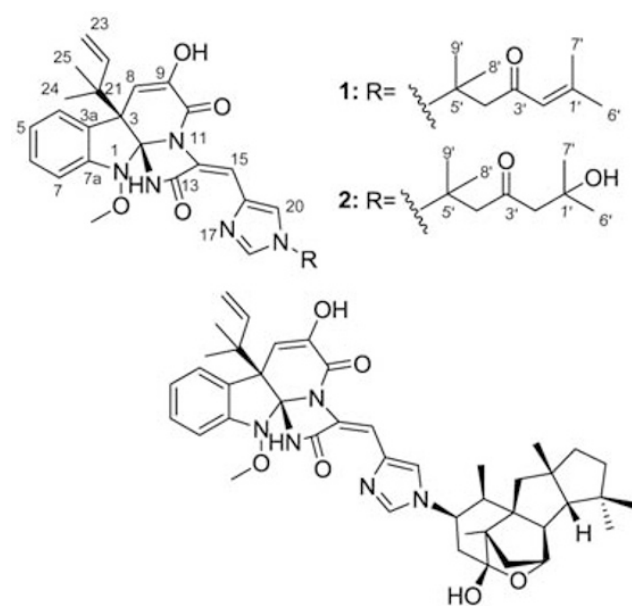

5. Meleagrin B
$J=17.6 \mathrm{~Hz}, \mathrm{H}-23 \mathrm{a})$ and $5.08(1 \mathrm{H}, \mathrm{brs}, \mathrm{H}-23 \mathrm{~b}) / \delta_{\mathrm{C}}: 42.8(\mathrm{C}-21), 143.3$ (C-22), 114.1 (C-23), 23.0 (C-24), 21.7 (C-25)), a histidine residue $\left(\delta_{\mathrm{H}}: 8.45(1 \mathrm{H}, \mathrm{s}, \mathrm{H}-15), 7.62(1 \mathrm{H}, \mathrm{s}, \mathrm{H}-18), 8.59(1 \mathrm{H}, \mathrm{s}, \mathrm{H}-20) / \delta_{\mathrm{C}}\right.$ : 123.6 (C-12), 163.7 (C-13), 117.7 (C-15), 135.3 (C-16), 134.4 (C-18), $122.2(\mathrm{C}-20))$ and an $\alpha, \beta$-unsaturated amide moiety $\left(\delta_{\mathrm{H}}: 5.45(1 \mathrm{H}, \mathrm{s}\right.$, $\mathrm{H}-8) / \delta_{\mathrm{C}}: 107.1$ (C-8), 141.9 (C-9), 158.8 (C-10)), which constituted a meleagrin alkaloid moiety (Figure 2). The ${ }^{1} \mathrm{H}$ and ${ }^{13} \mathrm{C}$ NMR spectra of 1 (Table 1) and meleagrin $\mathrm{C}^{11}$ were almost identical except for some tiny distinctions that are ascribed to the different substituents on $\mathrm{N}-19$. Analysis of the HMBC correlations from $\mathrm{CH}_{3}-6^{\prime}$ to $\mathrm{C}-1^{\prime}, \mathrm{C}-2^{\prime}$ and $\mathrm{C}-7^{\prime}$, from $\mathrm{H}-2^{\prime}$ to $\mathrm{C}-1^{\prime}, \mathrm{C}-3^{\prime}, \mathrm{CH}_{3}-6^{\prime}$ and $\mathrm{CH}_{3}-7^{\prime}$, from $\mathrm{H}-4^{\prime}$ to $\mathrm{C}-3^{\prime}, \mathrm{C}-5^{\prime}, \mathrm{C}-8^{\prime}$ and $\mathrm{C}-9^{\prime}$, and from $\mathrm{CH}_{3}-8^{\prime}$ to $\mathrm{C}-4^{\prime}, \mathrm{C}-5^{\prime}$ and $\mathrm{C}-9^{\prime}$ could afford an unprecedented 2,6-dimethylhept-2-en-4-one moiety connecting with the imidazole ring through the C-5'-N-19 single bond, which was confirmed by the NOESY correlations between $\mathrm{H}-20$ and $\mathrm{H}-8^{\prime}, \mathrm{H}-9^{\prime}$, and $2 \mathrm{H}-4^{\prime}$ (Figure 2). Thus the planar structure of $\mathbf{1}$ was established, namely meleagrin D (Figure 1). The absolute configuration of meleagrin (6), isolated from the same species, has been well established. ${ }^{11,12}$ By comparison of the 1D NMR data and the optical rotation values of meleagrin $\mathrm{D}(\mathbf{1})$ and meleagrin (6) with those reported for meleagrin, ${ }^{11,12}$ the absolute configurations of C-2, C-3 and the $\mathrm{C}-12 / \mathrm{C}-15$ double bond in 1 were deduced to be consistent with those in $\mathbf{6}$ on biogenetic grounds.

Compound 2 was a yellow solid with the molecular formula $\mathrm{C}_{32} \mathrm{H}_{39} \mathrm{~N}_{5} \mathrm{O}_{6}$, established by HR-ESI-MS $\left(m / z 590.2980[\mathrm{M}+\mathrm{H}]^{+}\right.$, calcd for 590.2979). A careful comparison of the ${ }^{1} \mathrm{H}$ and ${ }^{13} \mathrm{C}$ NMR data with those of compound $\mathbf{1}$ (Table 1) indicated that they had the same meleagrin moiety, but with the structure of the $\mathrm{N}-19$ substituent changed. The 1D NMR signals of the $\mathrm{sp}^{2}$ quaternary carbon $(\delta 157.1)$ and the $\mathrm{sp}^{2}$ methine $\left(\delta_{\mathrm{H}} 5.78(1 \mathrm{H}, \mathrm{s}) / \delta_{\mathrm{C}} 124.1\right)$ were replaced by those of an oxygen-bearing $\mathrm{C}-1^{\prime}(\delta 69.7)$ and a methylene $\mathrm{CH}_{2}-2^{\prime}\left(\delta_{\mathrm{H}} 2.40\right.$ $\left.(1 \mathrm{H}, \mathrm{d}, J=16.1 \mathrm{~Hz}), 2.35(1 \mathrm{H}, \mathrm{d}, J=16.1 \mathrm{~Hz}) / \delta_{\mathrm{C}} 54.9\right)$, and the chemical shifts of $\mathrm{C}^{-} 3^{\prime}, \mathrm{CH}_{3}-6^{\prime}$ and $\mathrm{CH}_{3}-7^{\prime}$ changed significantly (Table 1). It indicated that a novel 2-hydroxy-2,6-dimethylheptan-4one moiety, also confirmed by the HMBC correlations (Figure 2), was attached to the imidazole ring through the $\mathrm{C}-5^{\prime}-\mathrm{N}-19$ single bond. The structure of $\mathbf{2}$ was established as a new meleagrin analog, namely meleagrin E (Figure 1).

Compound 3 was a yellow solid. Its molecular formula was established as $\mathrm{C}_{28} \mathrm{H}_{33} \mathrm{~N}_{5} \mathrm{O}_{3}$ by HR-ESI-MS $\left(m / z 488.1674[\mathrm{M}+\mathrm{H}]^{+}\right.$,
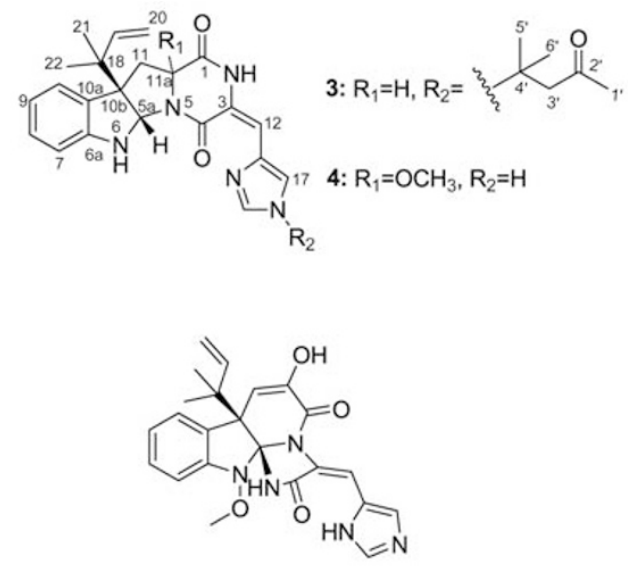

6. Meleagrin

Figure 1 Structures of compounds 1-6. 


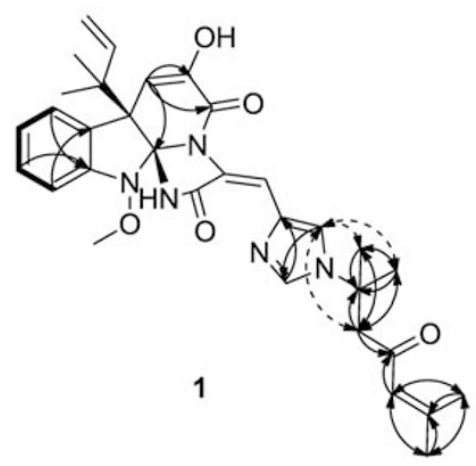

$-{ }^{1} \mathrm{H}-{ }^{1} \mathrm{H} \operatorname{COSY}$

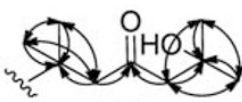

2<smiles>C=CC1(C(C)(C)C)c2ccccc2NC1N1NC(=O)/C(=C/c2c[nH]cn2)NC1=O</smiles>
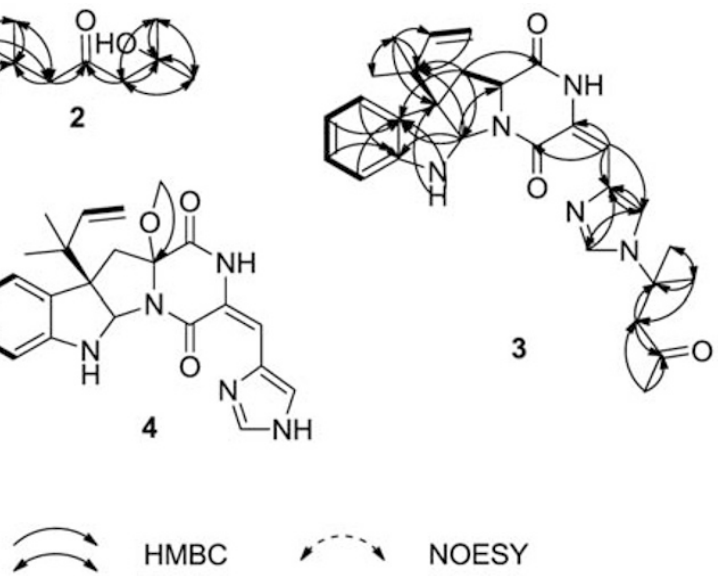

Figure 2 Key ${ }^{1} \mathrm{H}-{ }^{1} \mathrm{H}$ COSY, HMBC and NOESY correlations of compounds $\mathbf{1 - 4}$.

calcd for 488.2662). The ${ }^{1} \mathrm{H}$ NMR spectrum showed a characteristic $\mathrm{ABCD}$ system due to the aromatic resonances $(\delta 6.60(1 \mathrm{H}, \mathrm{d}$, $J=7.7 \mathrm{~Hz}, \mathrm{H}-7), 7.10(1 \mathrm{H}, \mathrm{t}, J=7.7 \mathrm{~Hz}, \mathrm{H}-8), 6.76(1 \mathrm{H}, \mathrm{t}, J=7.7 \mathrm{~Hz}$, $\mathrm{H}-9), 7.17(1 \mathrm{H}, \mathrm{d}, J=7.7 \mathrm{~Hz}, \mathrm{H}-10))$ and an ABX system assigned to the protons that comprised the exocyclic double bond $(\delta 5.99(1 \mathrm{H}, \mathrm{dd}$, $J=10.1,17.3 \mathrm{~Hz}, \mathrm{H}-19), 5.13(1 \mathrm{H}, \mathrm{d}, J=10.1 \mathrm{~Hz}, \mathrm{H}-20 \mathrm{a}), 5.10(1 \mathrm{H}, \mathrm{d}$, $J=17.3 \mathrm{~Hz}, \mathrm{H}-20 \mathrm{~b}))$. Analysis of the ${ }^{13} \mathrm{C}$ NMR and DEPT spectra revealed 10 quaternary carbons, 10 methines, 3 methylenes and 5 methyls. The ${ }^{1} \mathrm{H}-{ }^{1} \mathrm{H}$ COSY and HMBC spectra (Figure 2) confirmed that compound $\mathbf{3}$ has the same planar structure as roquefortine $\mathrm{C},{ }^{1}$ the biogenetic precursor of meleagrin, except for a minor substituent variation on $\mathrm{N}-16$. The structure of the substitute was established as 4-methylpentan-2-one by examining the HMBC correlations from $\mathrm{CH}_{3}-1^{\prime}$ to C-2' and C-3'; from $\mathrm{H}-3^{\prime}$ to $\mathrm{C}-2^{\prime}, \mathrm{C}-4^{\prime}, \mathrm{C}-5^{\prime}$ and $\mathrm{C}-6^{\prime}$; and from $\mathrm{CH}_{3}-5^{\prime}$ to $\mathrm{C}-3^{\prime}, \mathrm{C}-4^{\prime}$ and $\mathrm{C}-6^{\prime}$. Comparison of the $1 \mathrm{D}$ NMR spectra (Table 2) with those of meleagrin $\mathrm{C}^{11}$ further confirmed the same substituent system on the imidazole ring. Thus the planar structure of 3 was established, namely roquefortine $\mathrm{H}$ (Figure 1), and its absolute configurations of $\mathrm{C}-5 \mathrm{a}, \mathrm{C}-10 \mathrm{~b}, \mathrm{C}-11 \mathrm{a}$ and the C-3/C-12 double bond, by comparison of the 1D NMR data and the optical rotation values, were proposed to be the same as roquefortine $\mathrm{C}$, the absolute configuration of which has been established. ${ }^{13}$

Compound 4, a yellow solid, had the molecular formula $\mathrm{C}_{23} \mathrm{H}_{25} \mathrm{~N}_{5} \mathrm{O}_{3}$, as established by HR-ESI-MS $\left(m / z 420.2030[\mathrm{M}+\mathrm{H}]^{+}\right.$, calcd for 420.2036). Comparison of its ID NMR spectra with those of roquefortine $\mathrm{C}^{1}$ and compound 3 indicated that they had the same skeleton and that $\mathrm{N}-16$ in 4 was not substituted, but the H-11a $(\delta 4.05$ in 3) was replaced by an $\mathrm{OCH}_{3}\left(\delta_{\mathrm{H}} 2.84, \delta_{\mathrm{C}} 52.0\right)$. This structure was supported by the $\mathrm{HMBC}$ correlation from $\mathrm{OCH}_{3}-11 \mathrm{a}$ to $\mathrm{C}-11 \mathrm{a}$ $(\delta$ 91.2) and the doublet peaks of $\mathrm{H}-11 \alpha$ and $\mathrm{H}-11 \beta$. On further comparing the 1D NMR spectra with those of roquefortine $\mathrm{G},{ }^{11}$ they were found to have the same $\mathrm{OCH}_{3}-11$ a substitute and the chemical shifts for H-11 $\alpha, \mathrm{H}-11 \beta, \mathrm{C}-11, \mathrm{C}-11 \mathrm{a}, \mathrm{C}-1$ and $\mathrm{OCH}_{3}-11 \mathrm{a}$ (Table 2) $)^{11}$ were identical. As the absolute configuration of $\mathrm{C}-11 \mathrm{a}$ in roquefortine $\mathrm{G}$ has been established, ${ }^{11}$ the absolute configuration of compound 4 was deduced to be the same as that of roquefortine $\mathrm{G}$ on biogenetic ground and by their similar ${ }^{1} \mathrm{H}$ and ${ }^{13} \mathrm{C}$ shifts. The structure of $\mathbf{4}$ was established as a new roquefortine $\mathrm{C}$ analog, namely roquefortine $\mathrm{I}$ (Figure 1).

The biogenetic relationship of all the new alkaloids was postulated in a plausible route (Scheme 1). Biosynthetically, the unprecedented side chains of compounds $\mathbf{1}$ and $\mathbf{2}$ are proposed to originate from six acetates via the acetate-mevalonate pathway. Intermolecular Michael
Table $2{ }^{1} \mathrm{H}(600 \mathrm{MHz})$ and ${ }^{13} \mathrm{C}(150 \mathrm{MHz})$ NMR data for compounds 3 and 4 in $\mathrm{CDCl}_{3}$

\begin{tabular}{|c|c|c|c|c|}
\hline \multirow[b]{2}{*}{ NO } & \multicolumn{2}{|l|}{3} & \multicolumn{2}{|l|}{4} \\
\hline & $\delta_{H}(\mathrm{~J}$ in $H z)$ & $\delta_{C}$ & $\delta_{H}(\mathrm{~J}$ in $H z)$ & $\delta_{C}$ \\
\hline 1 & & 166.5 & & 163.4 \\
\hline 3 & & 123.4 & & 120.8 \\
\hline 4 & & 158.6 & & 160.7 \\
\hline $5 a$ & $5.65(1 \mathrm{H}, \mathrm{s})$ & 78.0 & $5.76(1 \mathrm{H}, \mathrm{s})$ & 79.7 \\
\hline $6 a$ & & 150.2 & & 148.7 \\
\hline 7 & $6.60(1 \mathrm{H}, \mathrm{d}, 7.7)$ & 109.1 & $6.60(1 \mathrm{H}, \mathrm{d}, 7.7)$ & 108.9 \\
\hline 8 & $7.10(1 \mathrm{H}, \mathrm{t}, 7.7)$ & 128.9 & $7.09(1 \mathrm{H}, \mathrm{t}, 7.7)$ & 128.4 \\
\hline 9 & $6.76(1 \mathrm{H}, \mathrm{t}, 7.7)$ & 118.9 & $6.76(1 \mathrm{H}, \mathrm{t}, 7.7)$ & 118.7 \\
\hline 10 & $7.17(1 \mathrm{H}, \mathrm{d}, 7.7)$ & 125.2 & $7.18(1 \mathrm{H}, \mathrm{d}, 7.7)$ & 124.5 \\
\hline $10 a$ & & 128.8 & & 129.9 \\
\hline $10 b$ & & 61.5 & & 60.0 \\
\hline $11 \alpha$ & $2.56(1 \mathrm{H}, \mathrm{dd}, 6.1,11.8)$ & 36.9 & $2.76(1 \mathrm{H}, \mathrm{d}, 13.9)$ & 39.4 \\
\hline $11 \beta$ & $2.47(1 \mathrm{H}, \mathrm{t}, 11.8)$ & & $2.55(1 \mathrm{H}, \mathrm{d}, 13.9)$ & \\
\hline $11 a$ & $4.05(1 \mathrm{H}, \mathrm{dd}, 6.1,11.8)$ & 58.9 & & 91.2 \\
\hline $11 \mathrm{a}-\mathrm{OCH}_{3}$ & & & $2.84(3 \mathrm{H}, \mathrm{s})$ & 52.0 \\
\hline 12 & $6.58(1 \mathrm{H}, \mathrm{s})$ & 117.7 & $6.37(1 \mathrm{H}, \mathrm{s})$ & 111.8 \\
\hline 13 & & 135.1 & & 125.0 \\
\hline 15 & $7.63(1 \mathrm{H}, \mathrm{s})$ & 134.7 & $7.74(1 \mathrm{H}, \mathrm{s})$ & 137.7 \\
\hline 17 & $8.45(1 \mathrm{H}, \mathrm{s})$ & 121.1 & $7.33(1 \mathrm{H}, \mathrm{s})$ & 134.5 \\
\hline 18 & & 41.0 & & 41.3 \\
\hline 19 & $5.99(1 \mathrm{H}, \mathrm{dd}, 10.1,17.3)$ & 143.5 & $5.95(1 \mathrm{H}, \mathrm{dd}, 11.0,17.2)$ & 143.3 \\
\hline $20 a$ & $5.13(1 \mathrm{H}, \mathrm{d}, 10.1)$ & 114.6 & $5.15(1 \mathrm{H}, \mathrm{d}, 11.0)$ & 115.0 \\
\hline $20 b$ & $5.10(1 \mathrm{H}, \mathrm{d}, 17.3)$ & & $5.12(1 \mathrm{H}, \mathrm{d}, 17.2)$ & \\
\hline 21 & $1.03(3 \mathrm{H}, \mathrm{s})$ & 22.9 & $1.01(3 \mathrm{H}, \mathrm{s})$ & 22.7 \\
\hline 22 & $1.14(3 \mathrm{H}, \mathrm{s})$ & 22.5 & $1.15(3 \mathrm{H}, \mathrm{s})$ & 22.2 \\
\hline $2-\mathrm{NH}$ & $8.72(1 \mathrm{H}, \mathrm{s})$ & & $8.22(1 \mathrm{H}, \mathrm{s})$ & \\
\hline $6-\mathrm{NH}$ & $4.98(1 \mathrm{H}, \mathrm{s})$ & & $5.03(1 \mathrm{H}, \mathrm{s})$ & \\
\hline $1^{\prime}$ & $2.01(1 \mathrm{H}, \mathrm{s})$ & 31.5 & & \\
\hline $2^{\prime}$ & & 204.9 & & \\
\hline 3'a & $2.97(1 \mathrm{H}, \mathrm{d}, 16.1)$ & 54.8 & & \\
\hline $3^{\prime} b$ & $2.94(1 \mathrm{H}, \mathrm{d}, 16.1)$ & & & \\
\hline $4^{\prime}$ & & 56.6 & & \\
\hline $5^{\prime}$ & $1.73(3 \mathrm{H}, \mathrm{s})$ & 27.8 & & \\
\hline $6^{\prime}$ & $1.74(3 \mathrm{H}, \mathrm{s})$ & 28.2 & & \\
\hline
\end{tabular}

addition ${ }^{11}$ of intermediates $(\mathbf{b})$ or (c) toh meleagrin (6), of which the biosynthetic pathway has been well established, ${ }^{14-16}$ would provide meleagrin E (2) and D (1), respectively. 


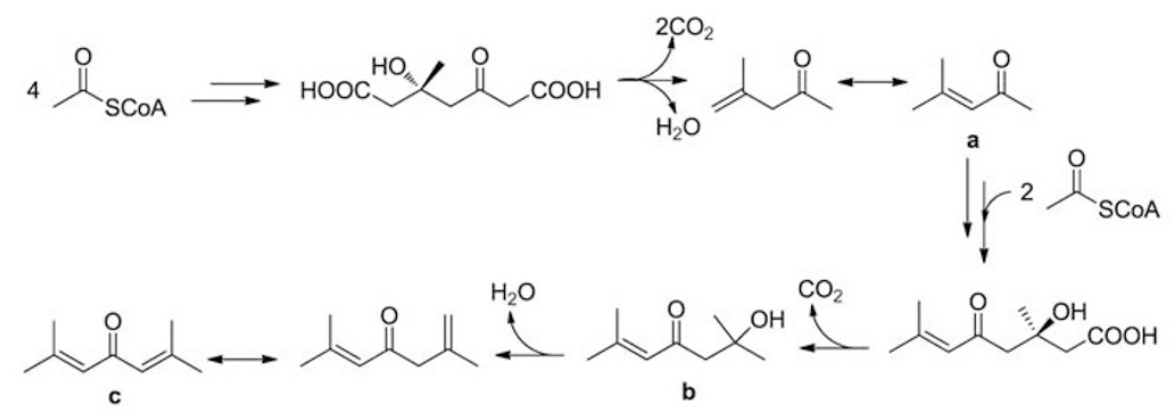
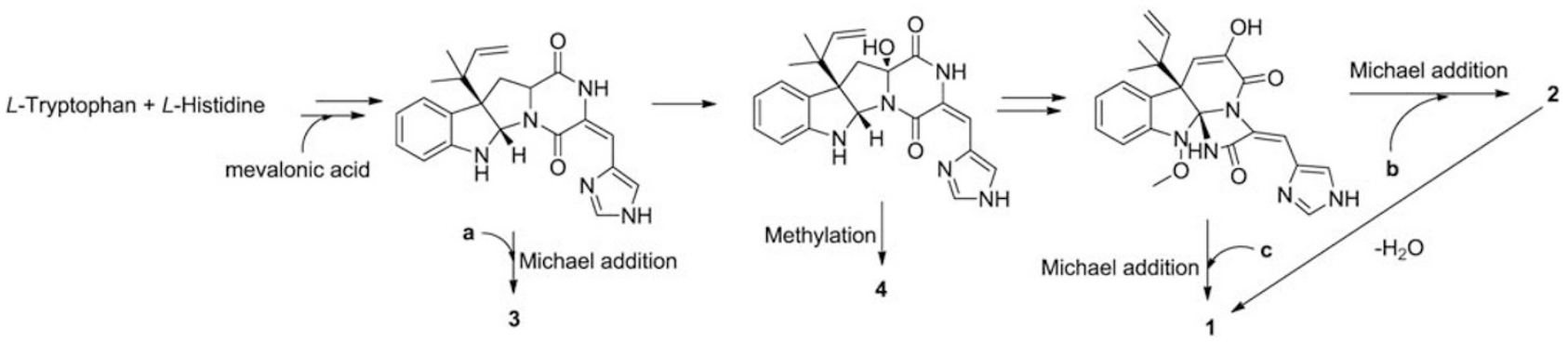

Scheme 1 Postulated biosynthetic pathway of compounds 1-4.

Table 3 Cytotoxicity data for compounds 1-6 against established cancer cell lines

\begin{tabular}{lcccccc}
\hline & \multicolumn{6}{c}{ Compd. } \\
\cline { 2 - 7 } Cytotoxicity $\left(I C_{50}, \mu \mathrm{M}\right)$ & $\mathbf{1}$ & $\mathbf{2}$ & $\mathbf{3}$ & $\mathbf{4}$ & $\mathbf{5}$ & $\mathbf{6}$ \\
\hline A-549 & 32.2 & 55.9 & $>100$ & $>100$ & 2.7 & 19.9 \\
HL-60 & $>100$ & $>100$ & $>100$ & $>100$ & 6.7 & 7.4 \\
\hline
\end{tabular}

\section{Cytotoxic activities}

The new compounds 1-4 and meleagrin (6) were evaluated for their cytotoxicity against the HL-60 cell line by the MTT method ${ }^{17}$ and against the A-549 cell line by the SRB method. ${ }^{18}$ Meleagrin D (1) and E (2) showed weak cytotoxicity against the A-549 cell line, while meleagrin (6) exhibited moderate cytotoxicity against the A-549 and HL-60 cell lines, with the $\mathrm{IC}_{50}$ values being 19.9 and $7.4 \mu \mathrm{M}$, respectively (Table 3). Comparison with the previous antitumor evaluation of meleagrin $\mathrm{B}$ (5) and $\mathrm{C}^{11}$ indicated that addition of the acetatemevalonate-derived $\mathrm{C} 5$ or $\mathrm{C} 9$ side chains on $\mathrm{N}-17$ negatively affects the activities of meleagrin alkaloids, while the diterpene substitution on the imidazole ring enhances the cytotoxic activities. The 9-Omethyl analog of meleagrin, oxaline, was reported to inhibit tubulin polymerization, resulting in cell cycle arrest through the $M$ phase in Jurkat cells. ${ }^{10}$ Therefore, we further explored the potential cytotoxic mechanisms of meleagrin B (5) and meleagrin (6) by flow cytometric analysis. ${ }^{19}$ Meleagrin B (5) induced HL-60 cell apoptosis at 5 and $10 \mu \mathrm{M}$, while meleagrin (6) arrested the cell cycle through $\mathrm{G}_{2} / \mathrm{M}$ phase at the same concentrations (Figure 3 ). The results indicted that meleagrin (6), similar to oxaline, is also an inhibitor of tubulin polymerization. Interestingly, addition of the diterpene moiety on the imidazole ring produces distinct cytotoxic mechanisms. It warrants further investigation on the real molecular targets of the novel alkaloid-diterpene complex compound meleagrin B (5).

\section{METHODS}

\section{General}

Specific rotations were obtained on a JASCO P-1020 digital polarimeter (JASCO Inc., Tokyo, Japan). UV spectra were recorded on Beckman DU 640 spectrophotometer (Beckman Coulter Inc., Brea, CA, USA). IR spectra were obtained on a NICOLET NEXUS 470 spectrophotometer (Thermo Electron Corporation, Madison, WI, USA) in $\mathrm{KBr}$ discs. ${ }^{1} \mathrm{H},{ }^{13} \mathrm{C}$ NMR and DEPT spectra and 2D-NMR were recorded on a JEOL JNM-ECP 600 spectrometer (JEOL Ltd., Tokyo, Japan) using TMS as internal standard, and chemical shifts were recorded as $\delta$ values. ESI-MS was measured on a Q-TOF ULTIMA GLOBAL GAA076 LC mass spectrometer (Waters Corporation, Milford, MA, USA). Semipreparative HPLC was performed using an ODS column (YMC-pak ODS-A, $10 \times 250$ mm, $5 \mu \mathrm{m}$ (YMC Co. Ltd., Kyoto, Japan), $\left.4 \mathrm{ml} \mathrm{min}^{-1}\right)$.

\section{Fungal material}

The fungus, strain F23-2, was obtained from a deep ocean sediment sample (depth $5080 \mathrm{~m}$ ). It was identified as Penicillium sp. by Professor Fengping Wang, School of Life Science \& Biotechnology, Shanghai Jiao Tong University, Shanghai, China, on the basis of its ribosomal internal transcribed spacers and the 5.8S ribosomal RNA gene (ITS1-5.8S-ITS2), which was deposited in Genbank (EU770318). Working stocks were prepared on potato dextrose agar slants stored at $4{ }^{\circ} \mathrm{C}$.

\section{Fermentation, extraction and isolation}

Spores growing on potato dextrose agar slant were inoculated into $1000-\mathrm{ml}$ Erlenmeyer flasks containing $200 \mathrm{ml}$ sea-water-based culture medium (potato $200 \mathrm{~g}$, glucose $20 \mathrm{~g}$, mannitol $20 \mathrm{~g}$, maltose $10 \mathrm{~g}$, peptone $5 \mathrm{~g}$, yeast extract $3 \mathrm{~g}$, dissolved in 1-1 seawater, $\mathrm{pH} 6.0$ ) and cultured at $28^{\circ} \mathrm{C}$ for 45 days under static conditions. In all, 1001 of the whole broth gave a crude ethyl acetate extract $(45.0 \mathrm{~g})$, which was subjected to silica gel column chromatography (petroleum ether-acetone, $\mathrm{v} / \mathrm{v}$, gradient). The active fractions 9 and 13 eluted with the solvent of petroleum ether-acetone (6:4 and 5:5) were separately subjected to repeated Sephadex LH-20 column chromatography (chloroform-methanol, 1:1; GE Healthcare, Uppsala, Sweden). The active subfractions 13-1-1, 13-12, 9-7-2 and 9-10-3 were further purified, respectively, by HPLC using a reversed-phase $\mathrm{C} 18$ column $\left(65 / 35 \mathrm{MeOH} / \mathrm{H}_{2} \mathrm{O}, 65 / 35 \mathrm{MeOH} / \mathrm{H}_{2} \mathrm{O}, 70 / 30\right.$ 

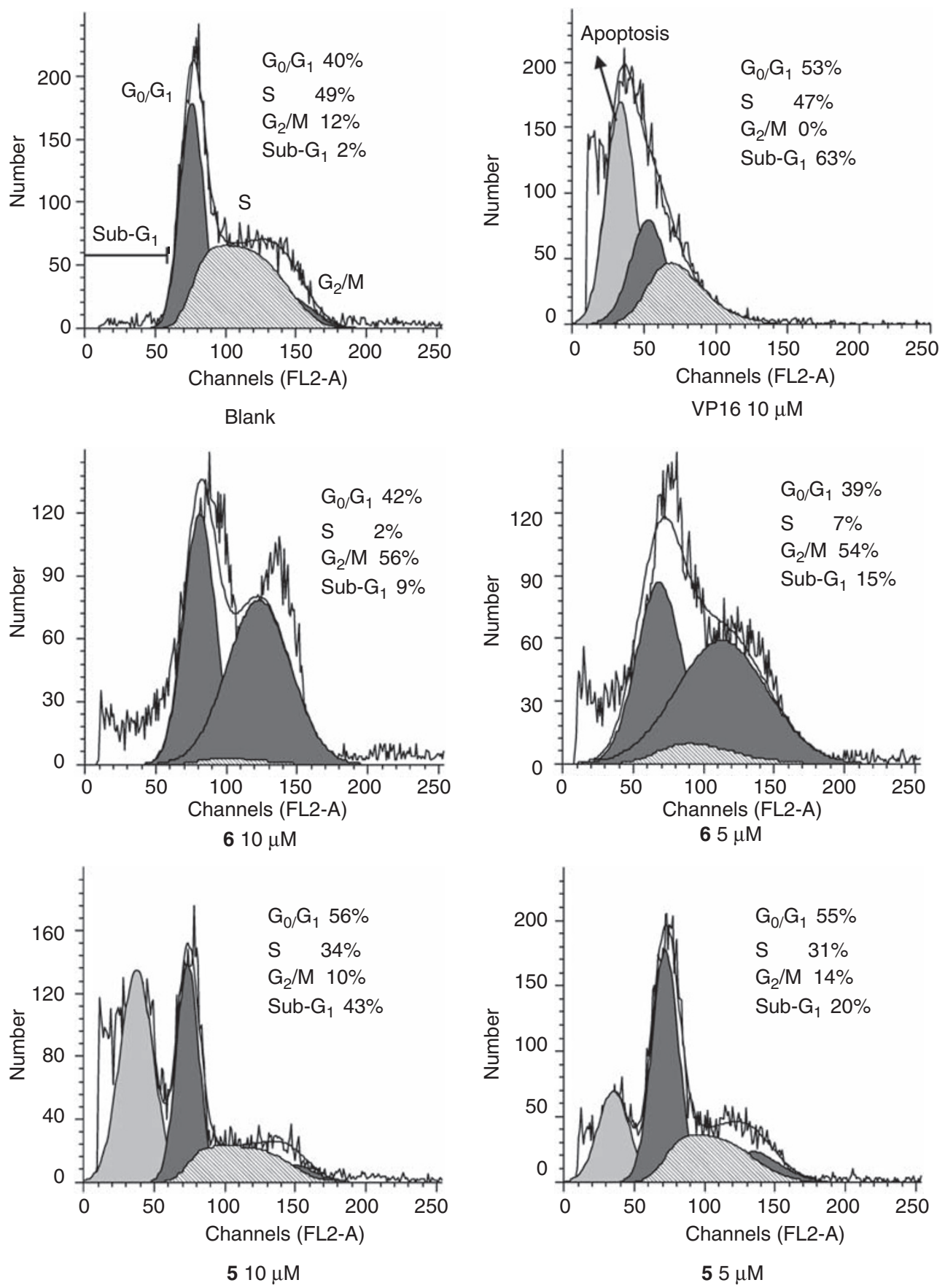

Figure 3 Flow cytometric analysis of compounds 5 and $\mathbf{6}$. HL-60 cells incubated with 5 and $6(5,10 \mu \mathrm{m})$ for $24 \mathrm{~h}$ were fixed and stained with PI. The percentage of cells with the hypodiploid DNA content was determined by flow cytometry. Results are representative of three separate experiments. VP16 $(10 \mu \mathrm{m})$ was used as a positive control.

$\mathrm{MeOH} / \mathrm{H}_{2} \mathrm{O}$ and $\left.65 / 35 \mathrm{MeOH} / \mathrm{H}_{2} \mathrm{O}, 4.0 \mathrm{ml} \mathrm{min}^{-1}\right)$, to give compounds 1 (3.2 mg), 2 (4.5 mg), 3 (3.2 mg) and 4 (5.0 mg).

\section{Physico-chemical properties}

Meleagrin D (1): yellow solid (methanol), [a] ${ }^{20} \mathrm{D}-116$ (c. 0.01, MeOH), UV $\lambda_{\max }(\mathrm{MeOH}) \mathrm{nm}(\log \varepsilon): 200$ (4.67), 231 (4.31), 341 (4.14), IR (KBr) cm ${ }^{-1}$ : 2972, 2939, 1699, 1646, 1348, 1109, 976, ${ }^{1} \mathrm{H}-\mathrm{NMR}\left(\mathrm{CDCl}_{3}, 600 \mathrm{MHz}\right)$ and ${ }^{13} \mathrm{C}-$ NMR $\left(\mathrm{CDCl}_{3}, 150 \mathrm{MHz}\right)$, see Table 1, HR-ESI-MS m/z: $572.2852[\mathrm{M}+\mathrm{H}]^{+}$ (calcd for $\mathrm{C}_{32} \mathrm{H}_{38} \mathrm{~N}_{5} \mathrm{O}_{5}$ : 572.2873).

Meleagrin E (2): yellow solid (methanol), [a] ${ }^{20} \mathrm{D}-55$ (c. $\left.0.01, \mathrm{MeOH}\right), \mathrm{UV}$ $\lambda_{\max }(\mathrm{MeOH}) \mathrm{nm}(\log \varepsilon): 200$ (4.59), 221 (4.23), 340 (4.15), IR (KBr) $\mathrm{cm}^{-1}$ : 2972, 2932, 1712, 1646, 1540, 1447, 1348, 1215, 1116, 917, ${ }^{1} \mathrm{H}-\mathrm{NMR}\left(\mathrm{CDCl}_{3}\right.$,
$600 \mathrm{MHz})$ and ${ }^{13} \mathrm{C}-\mathrm{NMR}\left(\mathrm{CDCl}_{3}, 150 \mathrm{MHz}\right)$, see Table 1 , HR-ESI-MS $m / z$ : $590.2980[\mathrm{M}+\mathrm{H}]^{+}$(calcd for $\mathrm{C}_{32} \mathrm{H}_{40} \mathrm{~N}_{5} \mathrm{O}_{6}: 590.2979$ ).

Roquefortine $\mathrm{H}$ (3): yellow solid (methanol), [a] ${ }^{20} \mathrm{D}-430$ (c. 0.01, $\mathrm{MeOH}$ ), $\mathrm{UV} \lambda_{\max }(\mathrm{MeOH}) \mathrm{nm}(\log \varepsilon): 200$ (3.98), 218 (3.65), 314 (3.66), IR (KBr) $\mathrm{cm}^{-1}: 2965,2919,1672,1407,1308,1195,1056,1016,917,{ }^{1} \mathrm{H}-\mathrm{NMR}\left(\mathrm{CDCl}_{3}\right.$, $600 \mathrm{MHz})$ and ${ }^{13} \mathrm{C}-\mathrm{NMR}\left(\mathrm{CDCl}_{3}, 150 \mathrm{MHz}\right)$, see Table 2, HR-ESI-MS $\mathrm{m} / \mathrm{z}$ : $488.2674[\mathrm{M}+\mathrm{H}]^{+}$(calcd for $\mathrm{C}_{28} \mathrm{H}_{34} \mathrm{~N}_{5} \mathrm{O}_{3}: 488.2662$ ).

Roquefortine I (4): yellow solid (methanol), $[\mathrm{a}]{ }^{20}{ }_{\mathrm{D}}-285$ (c. $\left.0.01, \mathrm{MeOH}\right)$, UV $\lambda_{\max }(\mathrm{MeOH}) \mathrm{nm}(\log \varepsilon): 200$ (3.38), $226(2.82), 326(2.78), \mathrm{IR}(\mathrm{KBr})$ $\mathrm{cm}^{-1}: 2965,2912,1686,1387,1241,1076,917,{ }^{1} \mathrm{H}-\mathrm{NMR}\left(\mathrm{CDCl}_{3}, 600 \mathrm{MHz}\right)$ and ${ }^{13} \mathrm{C}-\mathrm{NMR}\left(\mathrm{CDCl}_{3}, 150 \mathrm{MHz}\right)$, see Table 2, HR-ESI-MS $\mathrm{m} / z$ : 420.2030 $[\mathrm{M}+\mathrm{H}]^{+}$(calcd for $\mathrm{C}_{23} \mathrm{H}_{26} \mathrm{~N}_{5} \mathrm{O}_{3}: 420.2036$ ). 


\section{In vitro cytotoxicity assays}

The human promyelocytic leukemia HL-60 and lung adenocarcinoma A-549 cell lines were purchased from ATCC (Manassas, VA, USA). They were maintained in RPMI-1640 (HL-60) and Ham's F12K (A549) medium (GIBCO, Grand Island, NE, USA) supplemented with $10 \%$ heat-inactivated fetal bovine serum (GIBCO), L-glutamine $(2 \mathrm{mM})$, penicillin $\left(100 \mathrm{IU} \mathrm{ml}^{-1}\right)$ and streptomycin $\left(100 \mu \mathrm{g} \mathrm{ml}^{-1}\right)$, pH 7.4 in a humidified atmosphere of $95 \%$ air plus $5 \% \mathrm{CO}_{2}$ at $37^{\circ} \mathrm{C}$.

In the MTT assay, the cell line was grown in RPMI-1640 supplemented with $10 \%$ FBS under a humidified atmosphere of $5 \% \mathrm{CO}_{2}$ and $95 \%$ air at $37^{\circ} \mathrm{C}$. Cell suspensions $(200 \mu \mathrm{l})$ at a density of $5 \times 10^{4} \mathrm{cells} \mathrm{ml}^{-1}$ were plated in 96-well microtiter plates and incubated for $24 \mathrm{~h}$. The test compound solutions $(2 \mu \mathrm{l}$ in $\mathrm{MeOH})$ at different concentrations were added to each well and further incubated for $72 \mathrm{~h}$ under the same conditions. The MTT solution $(20 \mu \mathrm{l}$ of a $5 \mathrm{mg} \mathrm{ml}^{-1}$ solution in IPMI-1640 medium) was added to each well and incubated for $4 \mathrm{~h}$. An old medium $(150 \mu \mathrm{l})$ containing MTT was then gently replaced by DMSO and pipetted to dissolve any formazan crystals formed. Absorbance was then determined on a SPECTRA MAX PLUS plate reader (Molecular Devices, Sunnyvale, CA, USA) at $540 \mathrm{~nm}$.

In the SRB assay, cell suspensions $(200 \mu \mathrm{l})$ were plated in 96 -cell plates at a density of $2 \times 10^{5}$ cells ml $^{-1}$. Then the test compound solutions $(2 \mu \mathrm{l}$ in $\mathrm{MeOH})$ at different concentrations were added to each well and further incubated for $24 \mathrm{~h}$. Following drug exposure, the cells were fixed with $12 \%$ trichloroacetic acid and the cell layer was stained with $0.4 \%$ SRB. The absorbance of SRB solution was measured at $515 \mathrm{~nm}$. Dose-response curves were generated and the $\mathrm{IC}_{50}$ values were calculated from the linear portion of log dose-response curves.

In the flow cytometric analysis, cells were plated in six-well cell culture plates $\left(1 \times 10^{6}\right.$ cells per well), in triplicate, and then treated with $\mathrm{MeOH}$ (control), VP16 (10 $\mu \mathrm{M}$, positive control, purchased from Sigma (St Louis, MO, USA)) or the compounds 5 and $\mathbf{6}$ for $24 \mathrm{~h}$ at concentrations of 5 and $10 \mu \mathrm{M}$. Cells were harvested, washed twice with PBS, and the cellular DNA stained with $200 \mu \mathrm{l}$ propidium iodide $\left(50 \mu \mathrm{g} \mathrm{ml}^{-1}\right.$, RNase $1 \mu \mathrm{g} \mathrm{ml}^{-1}$, Triton X-100 0.1\%). After incubation at $4{ }^{\circ} \mathrm{C}$ for $20 \mathrm{~min}$, the cells were analyzed using flow cytometry (Becton-Dickinson, Vantage, San Diego, CA, USA).

\section{ACKNOWLEDGEMENTS}

This work was funded by the Chinese Ocean Mineral Resource R \& D Association (DY105-2-04).
1 Scott, P. M., Merrien, M. A. \& Polonsky, J. Roquefortine and iso-fumigaclavine A, metabolites from Penicillium roqueforti. Experientia. 32, 140-142 (1976).

2 Ohmomo, S., Oguma, K., Ohashi, T. \& Abe, M. Isolation of a new indole alkaloid, roquefortine D, from the cultures of Penicillium roqueforti. Agric. Biol. Chem. 42, 2387-2389 (1978).

3 Musuku, A et al. Isolation and structure determination of a new roquefortine-related mycotoxin from Penicillium verrucosum VAR. Cyclopium isolated from Cassava. J. Nat. Prod. 57, 983-987 (1994).

4 Kozlovsky, A. G., Vinokurova, N. G., Solov'eva, T. F. \& Buzilova, I. G. Nitrogencontaining secondary metabolites of microscopic fungi. Appl. Biochem. Microbiol. 32, 39-48 (1996)

5 Kozlovsky, A. G. et al. A new 16n-carboxyethyl derivative of 3,12-dihydroroquefortin. Heterocycles 60, 1639-1644 (2003).

6 Steyn, P. S. \& Vleggaa, R. Roquefortine, an intermediate in the biosynthesis of oxaline in cultures of Penicillium oxalicum. J. Chem. Soc. Chem. Commun. 560-561 (1983).

7 Clark, B., Capon, R. J., Lacey, E., Tennant, S. \& Gill, J. H. Roquefortine E, a diketopiperazine from an Australian isolate of Gymnoascusreessii. J. Nat. Prod. 68, 1661-1664 (2005).

8 Kopp, B. \& Rehm, H. J. Antimicrobial action of roquefortine. Eur. J. Appl. Microbiol. Biotechnol. 6, 397-401 (1979).

9 Aninat, C., Hayashi, Y., Andre, F. \& Delaforge, M. Molecular requirements for inhibition of cytochrome P450 activities by roquefortine. Chem. Res. Toxicol. 14, 1259-1265 (2001).

10 Koizumi, Y., Arai, M., Tomoda, H. \& Omura, S. Oxaline, a fungal alkaloid, arrests the cell cycle in $\mathrm{M}$ phaseby inhibition of tubulin polymerization. Biochim. Biophys. Acta 1693, 47-55 (2004)

$11 \mathrm{Du}$, L. et al. New alkaloids and diterpenes from a deep ocean sediment derived fungus Penicillium sp. Tetrahedron 65, 1033-1039 (2009).

12 Kawai, K., Nozawa, K., Nakajima, S. \& litaka, Y. Studies on fungal products. VII. The structures of meleagrin and 9-0-p-bromobenzoylmeleagrin. Chem. Pharm. Bull. 32, 94-98 (1984)

13 Yamaguchi, T., Nozawa, K., Nakajima, S., Kawai, K. \& Udagawa, S. Absolute configuration of roquefortine C, a tremorgenic mycotoxin. Maikotokishin 34, 29-32 (1991).

14 Kusch, J. \& Rehm, H. J. Regulation aspects of roquefortine production by free and Caalginate immobilized mycelia of Penicillium roqueforti. Appl. Microbiol. Biotechnol. 23, 394-399 (1986).

15 Reshetilova, T. A., Vinokurova, N. G., Khmelenina, V. N. \& Kozlovskii, A. G. The role of roquefortine in the synthesis of alkaloids meleagrine, glandicolines-a and glandicolines-b, and oxaline in fungi Penicillium glandicola and P.atramentosum. Microbiology 64, 27-29 (1995).

16 Williams, R. M., Stoching, E. M. \& Sanz-Cervera, J. F. Biosynthesis of prenylated alkaloids derived from tryptophan. Top. Curr. Chem. 209, 97-173 (2000).

17 Mosmann, T. Rapid colorimetric assay for cellular growth and survival: application to proliferation and cytotoxicity assays. J. Immunol. Methods 65, 55-63 (1983).

18 Skehan, $\mathrm{P}$ et al. New colorimetric cytotoxicity assay for anticancer-drug screening. J. Natl Cancer Inst. 82, 1107-1112 (1990).

$19 \mathrm{Du}, \mathrm{L}$ et al. Cytotoxic sorbicillinoids and bisorbicillinoids from a marine-derived fungus Trichoderma sp. Chem. Pharm. Bull. 57, 220-223 (2009). 